\title{
How Effective Has ECB's Monetary Policy Been during Crisis? The Case of CDS Spreads and Bond Yields
}

\author{
Spyros I. Spyrou
}

\begin{abstract}
In this paper, the first Principal Component is extracted from weekly sovereign Eurozone CDS spreads and bond yields, and is then used in a regression with ECBs weekly holdings on three programs used during the EU crisis as explanatory variables. The monetary policy measures adopted by the ECB during the escalation of the $\mathrm{EU}$ financial crisis seem to have a statistically significant and negative effect on the CDS spreads and Bond Yields of the Eurozone countries. To the extent that the level of the CDS spreads and sovereign yields reflects market risks, default risk, and uncertainty, the significant and negative effect indicates that the measures adopted by the ECB were successful in reducing uncertainty in Eurozone markets.
\end{abstract}

Index Terms - CDS spreads, ECB monetary policy, principal components analysis.

\section{INTRODUCTION}

In normal times, the standard monetary policy instrument of central banks is their key interest rate. During the recent financial crisis, however, main rates reached their effective lower bound, exhausting central bank ability to provide additional monetary stimulus and perform their main role. In response to the EU crisis, the European Central Bank (ECB) implemented a number of unconventional (non-standard) monetary policy measures. These measures involved the expansion of the central bank's balance sheet (e.g., among other, through direct purchase of assets) in order to affect the functioning of different market segments and influence prices and yields. The main aim of these policies was to restore the mechanism through which monetary policy is transmitted.

One important policy transmission channel is the sovereign credit risk channel (see, among others, Fratzscher, et al. 2014 [1]). In this paper, the effectiveness of monetary policy transmission through the sovereign credit risk channel is examined. To this end, ECB holdings on three operations are employed in order to study their impact on sovereign Credit Default Swap (CDS) spreads and Sovereign Bond Yields (BY) for Eurozone countries. Spreads and yields reflect a number of risks such as default risk, general market risk, liquidity risk, and uncertainty. More specifically, the first principal component is first extracted from each set of variables and is then used as a left-hand side variable in a regression with explanatory variables current and lagged values of the

Manuscript received March 6, 2018; revised May 10, 2018. The author acknowledges financial support from the Research Centre at Athens University of Economics and Business (RC-AUEB).

Spyros Spyrou is with the Department of Accounting and Finance, Athens University of Economics and Business, Patision 76, 10434, Athens, Greece (e-mail: sspyrou@ aueb.gr). monetary policy variables.

The ECB to provides liquidity to European banks is via the short-term open Main Refinancing Operations (MROs). MROs tend to send signals to the market regarding monetary policy in the euro-zone and affect directly short-term interest rates. To deal with the financial crisis, however, other operations, such as the Long-Term Refinancing Operation (LTRO), were also introduced. This operation was designed to provide low cost financing to Euro-zone financial institutions with sovereign debt securities serving as a loan collateral. The maturity was typically three months to a year, however, on December 2011 the ECB announced a three-year LTRO (maturing in early 2015). The objective was to provide long-term financing at attractive rates (e.g. the 3-year LTRO in 2011 had an interest rate of 1\%) in order to avoid a crisis in the banking system and stimulate bank lending to the real economy. For example, the LTRO in February 2012 provided 529.5 billion $€$ in low interest loans to 800 banks. In addition, the Securities Markets Programme (SMP) was initiated in May 2010 and consisted of purchases of debt securities of many euro-zone members with the objective of restoring liquidity and depth in these markets, in order for the transmission mechanism to work properly. The ECB was also re-absorbing the injected liquidity on a weekly basis via liquidity-absorbing operations in order to keep the monetary policy position unaffected (sterilization). On September 2012, the SMP was terminated with the liquidity absorption operations to continue as in the past and the existing securities in the portfolio to be held until maturity (ECB, Eurosystem, Press Release, 6/9/2012). For example, in December 2012 the SMP holdings consisted of sovereign bonds issued by Ireland, Greece, Spain, Italy, and Portugal with nominal amounts of $14.2,33.9,44.3,102.8,22.8$ billion $€$ respectively (218 billion in total) and an average remaining maturity 4.3 years (ECB, Eurosystem, Press Release, 21/2/2013).

The results indicate that the monetary policy measures adopted by the ECB during the escalation of the EU financial crisis had a statistically significant and negative effect on the CDS spreads and bond Yields of the Eurozone countries. This implies that the measures adopted by the ECB were successful in reducing uncertainty and volatility in Eurozone markets, during the EU financial crisis. The rest of the paper is organized as follows: Section II reviews the data and the methodology, Section III presents the results, while Section IV concludes the paper.

\section{DATA AND TESTING Methodology}

For the empirical analysis, weekly sovereign Credit Default Swap (CDS) spreads are employed for Austria (AUS), Belgium (BEL), France (FR), Germany (GER), Ireland (IR), 
Italy (IT), Netherlands (NL), Portugal (PO), and Spain (SP). To test the robustness of the results with respect to the assets used, all tests are repeated for weekly sovereign Benchmark Bond yields for the same countries. The sample period is between 5/17/2010 and 9/26/2016 (333 weekly observations). Greece is excluded from the sample since trading on Greek CDS stopped in March 2012, and Cyprus due to some missing data. The monetary policy of ECB during the crisis is captured by the weekly holdings for three programmes: Main Refinancing Operations (MRO), Security Markets Program (SMP), and Longer-Term Refinancing Operations (LTR); SMP and LTR holdings proxy for unconventional policies. All data are collected from Thomson Reuters, Datastream.

Since for some countries the crisis had a more significant financial impact than for others, in addition to the full sample two sub-samples are also employed as follows: the first sub-sample includes Austria, Belgium, France, Germany, and the Netherlands (denoted "North" countries for simplicity), while the second sub-sample includes the countries that experienced more severe financial difficulties (e.g. received aid packages, etc.), that is, Ireland, Italy, Portugal, and Spain (denoted "South" countries for simplicity). Fig. 1 presents the CDS spreads for the two sub-samples, while Fig. 2 presents the European Central Bank Holdings. To test for a unit root on the $\log$ series the Kwiatkowski-Phillips-Schmidt-Shin (KPSS) test is employed (Panel C) which indicates that series are stationary around a deterministic trend (trend-stationary). This is not a surprising finding for CDS or credit spreads, since empirical evidence often finds weak evidence for a unit root in levels of credit spreads or CDS spreads (see Dieckmann and Plank, 2012 [2]; Cremers et al., 2008 [3]).
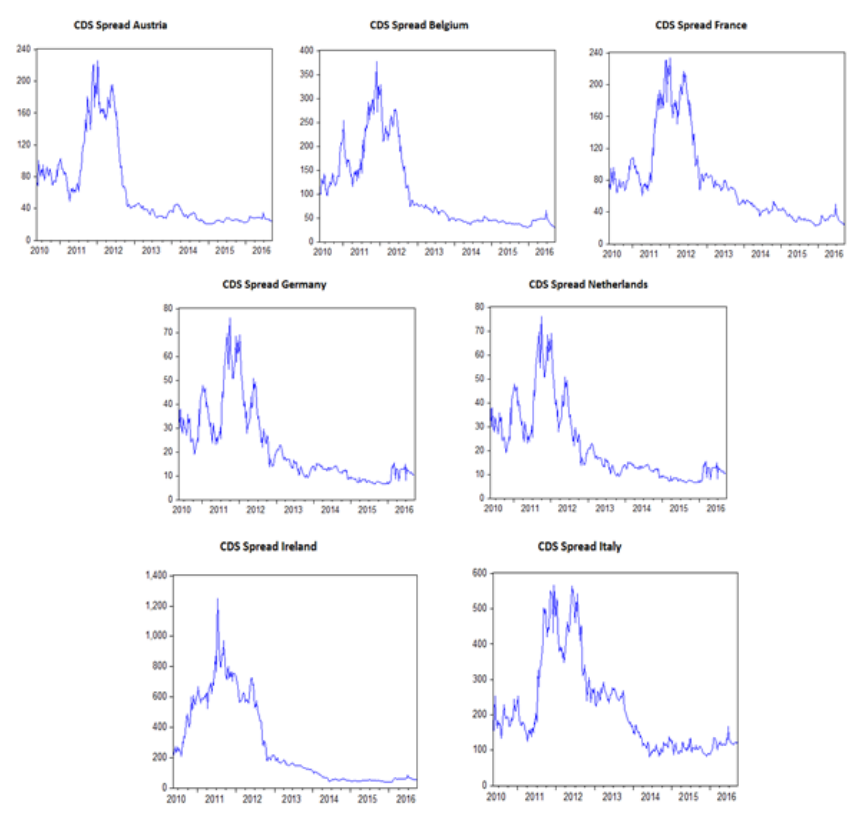

cos spread titaly
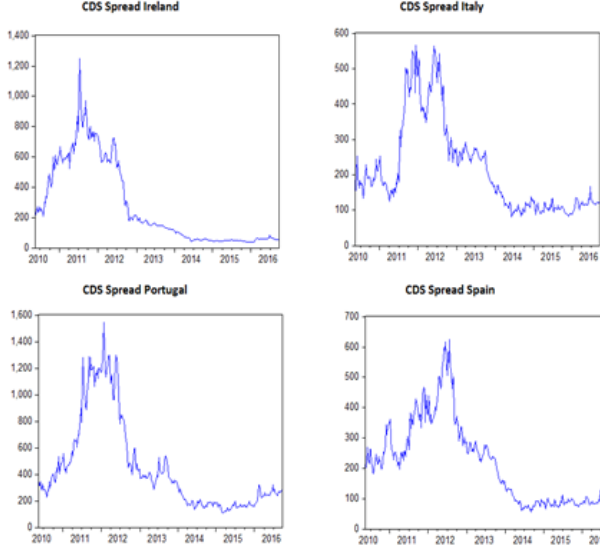

cos Spread Spain

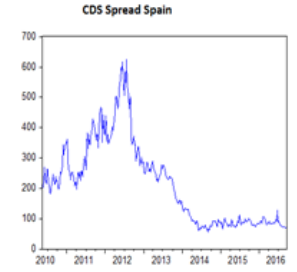

Fig. 1. CDS spreads in basis points.

For the empirical analysis, Principal Components Analysis (PCA) is employed. PCA is useful in obtaining the underlying behaviour in terms of a singular value decomposition of the data matrix (Thornhill and Naim, 2006 [4]); it uses linear combinations (components) of a set of variables in order to model the structure of their variance. The main combinations (principal components, PC) are obtained via an orthogonal transformation and the estimation of the eigenvalue decomposition of the variance matrix, while the first PC accounts for as much of the volatility as possible (for details see, among others, Chatfield and Collins, 1980 [5]).

Liu, et al. (2015) [6] point out that the linear combinations are independent and contain all the information about the original variables. PCA has been used in many financial analysis applications. For example, among others, Hasbrouck and Seppi (2001) [7] employ PCA in order to explain the total variance of variables such as stock returns or order flows across firms, or Brown and Cliff (2004) [8] who use PCA in order to extract composite unobserved sentiment variables. In a similar spirit, Baker and Wurgler (2006) [9] employ the first principal component of various sentiment proxies (the average closed-end fund discount, turnover, first day returns on Initial Public Offerings, share of equity in new issues, the dividend premium) in order to construct their well-known sentiment index.

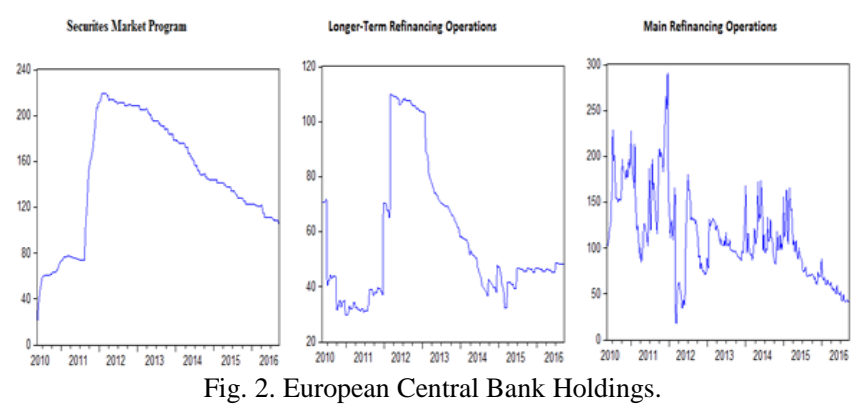

More specifically, the first principal component (PC1) is first extracted from each set of (log) variables and then use it as a left-hand side variable in a regression with explanatory variables current and lagged values of the (log) monetary policy variables, as follows:

$$
P C 1_{i t}=a+\sum_{j=1}^{J} \beta_{j t} X_{j t}+\varepsilon_{i t}
$$

In (1), is the is first principal component of sample $\mathrm{i}$ (full sample, "north" countries, "south" countries) during week t, $\mathrm{X}$ are the $\mathrm{j}$ current and lagged explanatory variables (LMRO, LSMP, LLTR), is an intercept coefficient, 's are the slope coefficients, and are the i.i.d. disturbance terms. The significance and sign of the slope coefficients will indicate whether contemporaneous and lagged monetary policy measures had an impact on CDS spreads and sovereign bond yields. Note that Dieckmann and Plank (2012) [2] adopt a similar approach in order to examine the factors that underlie the commonality in the sovereign CDS markets for 18 advanced economies, i.e. they extract the first PC and then regress it on ten global factors commonly employed in modelling credit risk.

\section{RESULTS}

Table I presents results on the proportion of total variance 
explained for by the first three principal components for each sample variables. Panel A presents results for Sovereign Credit Default Swap Spreads, while Panel B presents results for the Sovereign 10-year Benchmark Bond Yields. The first principal component (PC1) of the CDS spreads (Panel A) for the full sample explains approximately $91 \%$ of the total sample variance and the second a further $4.15 \%$. For the north and south sub-samples PC1 explains $93.85 \%$ and $92.72 \%$, respectively. The results for the bond yields (Panel B) are similar with the exception of the north countries, where PC1 explains $98.08 \%$ of the total variance.

TABLE I: PRINCIPAL COMPONENTS ANALYSIS THE PROPORTION OF TOTAL VARIANCE EXPLAINED

\begin{tabular}{|c|c|c|c|c|c|c|}
\hline \multirow[b]{3}{*}{$\begin{array}{l}\text { Principal } \\
\text { Component }\end{array}$} & \multicolumn{6}{|c|}{ Panel A: Sovereign Credit Default Swap Spreads } \\
\hline & \multicolumn{2}{|c|}{$\begin{array}{c}\text { All } \\
(\mathrm{N}=9)\end{array}$} & \multicolumn{2}{|c|}{$\begin{array}{l}\text { North } \\
(\mathrm{N}=5)\end{array}$} & \multicolumn{2}{|c|}{$\begin{array}{l}\text { South } \\
(\mathrm{N}=4)\end{array}$} \\
\hline & Proportion & $\begin{array}{l}\text { Cumulative } \\
\text { Proportion }\end{array}$ & Proportion & $\begin{array}{l}\text { Cumulative } \\
\text { Proportion }\end{array}$ & Proportion & $\begin{array}{l}\text { Cumulative } \\
\text { Proportion }\end{array}$ \\
\hline $\mathrm{PC} 1$ & 0.9113 & 0.9113 & 0.9385 & 0.9385 & 0.9272 & 0.9272 \\
\hline $\mathrm{PC} 2$ & 0.0415 & 0.9527 & 0.0355 & 0.9740 & 0.0449 & 0.9722 \\
\hline \multirow[t]{3}{*}{$\mathrm{PC} 3$} & 0.0184 & 0.9712 & 0.0130 & 0.9870 & 0.0231 & 0.9952 \\
\hline & \multicolumn{6}{|c|}{ Panel B: Sovereign 10-year Benchmark Bond Yields } \\
\hline & \multicolumn{2}{|c|}{$\begin{array}{c}\text { All } \\
(\mathrm{N}=9)\end{array}$} & \multicolumn{2}{|c|}{$\begin{array}{l}\text { North } \\
(\mathrm{N}=5)\end{array}$} & \multicolumn{2}{|c|}{$\begin{array}{l}\text { South } \\
(\mathrm{N}=4)\end{array}$} \\
\hline $\begin{array}{l}\text { Principal } \\
\text { Component }\end{array}$ & Proportion & $\begin{array}{l}\text { Cumulative } \\
\text { Proportion }\end{array}$ & Proportion & $\begin{array}{l}\text { Cumulative } \\
\text { Proportion }\end{array}$ & Proportion & $\begin{array}{l}\text { Cumulative } \\
\text { Proportion }\end{array}$ \\
\hline PC1 & 0.9197 & 0.9197 & 0.9808 & 0.9808 & 0.9102 & 0.9102 \\
\hline $\mathrm{PC} 2$ & 0.0624 & 0.9821 & 0.0091 & 0.9899 & 0.0744 & 0.9846 \\
\hline $\mathrm{PC} 3$ & 0.0061 & 0.9882 & 0.0079 & 0.9978 & 0.0120 & 0.9966 \\
\hline
\end{tabular}

TABLE II: THE EFFECT OF ECB POLICY ON CDS SPREADS

\begin{tabular}{|c|c|c|c|c|c|c|c|c|c|c|c|}
\hline & \multicolumn{3}{|c|}{$\begin{array}{c}\text { Panel A } \\
\text { First Principal Component } \\
\text { Sovereign 5-year CDS Spread } \\
\text { (Log Level) }\end{array}$} \\
\end{tabular}

Table II presents the results for regression (1); Panel A for the full sample, Panel B for the south markets, Panel C for the north markets. In order to gain further insight of the impact of unconventional monetary policy the sample period is further split into two sub-periods i.e. between 5/17/2010 and 30/09/2012, when the EU financial crisis erupted and escalated (and the SMP was terminated), and between 01-10-2012 and 9/26/2016, when the financial magnitude of the crisis was reduced, along with ECD holdings and spreads (see Figs. 1, 2, 3).

The Table presents slope coefficients and p-values for the coefficients, for all three sub-samples and the two sub-periods Although both current and lagged coefficients are reported, the focus should be more on the lagged coefficients since they contain information on the market reaction following an ECB move. For example, as can be seen in the first column, for the full sample (Panel A) and for the 2010-2012 sub-period, the previous week's SMP log level $(\operatorname{LSMP}(-1))$ had a negative $(-8.35)$ and statistically significant (p-value: 0.02$)$ effect on the current level of CDS-PC1. This also holds for the previous week's LTR log level (LLTR(-1)) which had a negative (-3.01) and statistically significant (p-value: 0.05 ) effect on the current level of CDS-PC1. During the 2012-2016 sub-period, no explanatory variable seems to have a statistically significant effect on the PC1 for the full sample (3rd and 4th column). The results are similar in Panels $\mathrm{B}$ and $\mathrm{C}$ with one exception: for the south markets (Panel B) the lagged MRO level $(\operatorname{LMRO}(-1))$ is also negative $(-0.42)$ and statistically significant (p-value: 0.06), for the crisis period.

These results seem to suggest that the monetary policy measures adopted by the ECB during the escalation of the financial crisis had a statistically significant and negative effect on the CDS spreads of the Eurozone countries. To the extent that the level of the CDS spread reflects market risks, default risks, uncertainty, and a deterioration of the financial health of the issuer of the underlying instrument, the negative sign indicates that the measures adopted by the ECB were successful in reducing uncertainty and volatility in Eurozone markets.

In order to test the robustness of the results with respect to the asset used in the empirical testing, the analysis is repeated for sovereign bond yields and the results are reported in Table III (organized in the same manner as Table III). The results are qualitatively similar, i.e. the lagged LLTR and LMRO variables seem to have a negative and statistically significant effect on the Yield-PC1 during the crisis for all sub-samples (except for the LMRO for the north countries). Also, LMRO and SMP seems to be significant for the south markets for the 2012-2016 period as well.

TABLE III: THE EFFECT OF ECB POLICY ON SOVEREIGN BOND YIELDS

\begin{tabular}{|c|c|c|c|c|c|c|c|c|c|c|c|c|}
\hline \multirow{3}{*}{ Period } & \multicolumn{4}{|c|}{$\begin{array}{c}\text { Panel A } \\
\text { First Principal Component } \\
\text { Sovereign 10-year Bond Yield } \\
\text { (Log Level) } \\
\text { All Sample Markets }\end{array}$} & \multicolumn{4}{|c|}{$\begin{array}{c}\text { Panel B } \\
\text { First Principal Component } \\
\text { Sovereign 10-year Bond Yield } \\
\text { (Log Level) } \\
\text { "South" Eurozone Markets }\end{array}$} & \multicolumn{4}{|c|}{$\begin{array}{c}\text { Panel C } \\
\text { First Principal Component } \\
\text { Sovereign 10-year Bond Yield } \\
\text { (Log Level) } \\
\text { "North" Eurozone Markets }\end{array}$} \\
\hline & \multicolumn{2}{|c|}{$2010-2012$} & \multicolumn{2}{|c|}{$2012-2016$} & \multicolumn{2}{|c|}{$2010-2012$} & \multicolumn{2}{|c|}{$2012-2016$} & \multicolumn{2}{|c|}{$2010-2012$} & \multicolumn{2}{|c|}{$2012-2016$} \\
\hline & $\beta_{i}$ & $\begin{array}{c}p \\
\text { value }\end{array}$ & $\beta_{i}$ & $\begin{array}{c}p \\
\text { value }\end{array}$ & $\beta_{i}$ & $\begin{array}{c}p \\
\text { value }\end{array}$ & $\beta_{i}$ & $\begin{array}{c}p \\
\text { value }\end{array}$ & $\beta_{i}$ & $\begin{array}{c}p \\
\text { value }\end{array}$ & $\beta_{i}$ & $\begin{array}{c}p \\
\text { value }\end{array}$ \\
\hline C & 23.31 & 0.00 & -27.54 & 0.00 & 11.97 & 0.00 & -28.78 & 0.00 & 22.46 & 0.00 & -12.77 & \begin{tabular}{|l|}
0.17 \\
\end{tabular} \\
\hline LSMP & -1.33 & 0.22 & -1.52 & 0.87 & 1.44 & 0.23 & -0.46 & 0.90 & -2.21 & 0.01 & -0.98 & 0.92 \\
\hline $\operatorname{LSMP}(-1)$ & 2.19 & 0.05 & 18.03 & 0.05 & -0.19 & 0.87 & 8.76 & 0.01 & 2.46 & 0.00 & 14.68 & \begin{tabular}{|l|}
0.13 \\
\end{tabular} \\
\hline LLTR & -0.50 & 0.34 & -1.84 & 0.40 & 0.03 & 0.95 & -0.28 & 0.73 & -0.61 & 0.11 & -1.82 & 0.42 \\
\hline $\operatorname{LLTR}(-1)$ & -1.08 & 0.03 & -0.90 & 0.67 & -1.07 & 0.06 & 0.41 & 0.61 & -0.75 & 0.04 & -1.57 & \begin{tabular}{|l|}
0.47 \\
\end{tabular} \\
\hline LMRO & -0.09 & 0.61 & -0.94 & 0.18 & 0.16 & 0.39 & -0.80 & 0.00 & -0.20 & 0.11 & -0.45 & \begin{tabular}{|l|l|}
0.53 \\
\end{tabular} \\
\hline LMRO $(-1)$ & -0.27 & 0.12 & -0.90 & 0.20 & -0.38 & 0.05 & -0.59 & 0.03 & -0.15 & 0.24 & -0.64 & \begin{tabular}{|l|}
0.37 \\
\end{tabular} \\
\hline$A d j-R^{2}$ & & & & & & & & & & & & \\
\hline
\end{tabular}

In order to test the robustness of the results Factor Analysis (FA) is also employed. Whilst PCA aims to determine the orthogonal linear combinations that maximize total variance without any prior assumptions about the form of the covariance matrix, FA examines the sample variables for common response variations to (unobserved) latent variables, i.e. looks for linear combinations that maximize the shared portion of the variance. FA also accounts for the random measurement error and the correlation matrix has in the diagonals the unique factors. It is beyond the scope of this paper to examine the (unobserved) factors that explain sovereign CDS spreads.

Instead, the aim here is to determine the main underlying factor that reflects the variation of the CDS sample variables, and then employ this factor as in equation (1) instead of the PC1. The intuition here is that we are interested on whether unconventional monetary policy measures have an impact on 
the main unobserved factor that drives CDS spreads, rather than the main PC that explains total variance. The results are discussed but not reported here (available upon request). For the full sample, two factors are suggested that explain $84.44 \%$ and $15.53 \%$ of the variance; the regression results are presented in Table $\mathrm{V}$ and are similar to the results obtained with the PCA analysis. For example, lagged SMP (MRO) holdings have a negative and significant impact on the main unobserved factor that drives CDS only during the crisis period for all three samples (south and north markets sub-sample).

\section{CONCLUSION}

During the recent financial crisis, main rates reached their effective lower bound, exhausting central bank ability to provide additional monetary stimulus and perform their main role. In response, the ECB implemented a number of non-standard monetary policy measures, which involved the expansion of its balance sheet, with the main aim to restore the mechanism through which monetary policy is transmitted. This paper examines the effectiveness of these policies on one important monetary policy transmission channel, the sovereign credit risk channel. Using principal component and factor analysis, CDS spreads, sovereign bond yields, and ECB holding on three operations (MRO, SMP, LTRO), for a sample of Eurozone countries, I find that the monetary policy measures adopted by the ECB during the escalation of the EU financial crisis had a statistically significant and negative effect on the CDS spreads and bond Yields of the Eurozone countries. To the extent that the level of the CDS spreads and sovereign yields reflects market risks, default risk, uncertainty, the significant and negative effect indicates that the measures adopted by the ECB were successful in reducing uncertainty and volatility in Eurozone markets.

\section{REFERENCES}

[1] M. Fratzscher, M. L. Duca, and R. Straub, "ECB unconventional monetary policy actions: Market impact, international spillovers and transmission channels," Paper presented at the 15th Jacques Polak Annual Research Conference Hosted by the International Monetary Fund, Washington-DC, November 13-14, 2014.

[2] S. Dieckmann, T. Plank, "Default Risk of Advanced Economies: An Empirical Analysis of Credit Default Swaps during the Financial Crisis," Review of Finance, vol. 16, no. 4, pp. 903-934, 2012.

[3] M. Cremers, J, Driessen, P. Maenhout, D. Weinbaum. "Individual Stock-Option Prices and Credit Spreads," Journal of Banking and Finance, vol. 32, pp. 2706-2715, 2008.

[4] N.F. Thornhill, M.M. Naim, "An exploratory study to identify rogue seasonality in a steel company's supply network using spectral principal component analysis," European Journal of Operational Research, vol. 172, no. 1, pp. 146-162, 2006.

[5] C. Chatfield and A. Collins, Principal component analysis in “Introduction to Multivariate Analysis," Springer, US, pp. 57-81, 1980.

[6] B. Liu, Y. Shen, W. Zhang, X. Chen, and X. Wang, "An interval-valued intuitionistic fuzzy principal component analysis model-based method for complex multi-attribute large-group decision-making," European Journal of Operational Research, vol. 245, no. 1, pp. 209-225, 2015.

[7] J. Hasbrouck and D. J. Seppi, "Common factors in prices, order flows and liquidity," Journal of Financial Economics, vol. 59, no. 3, pp. 383-411, 2001.

[8] G. W. Brown and M. T. Cliff, "Investor sentiment and the near-term stock market," Journal of Empirical Finance, vol. 11, pp. 1-27, 2004.

[9] M. Baker and J. Wurgler, "Investor sentiment and the cross-section of stock returns," The Journal of Finance, vol. 61, no. 4, pp. 1645-1680, 2006.

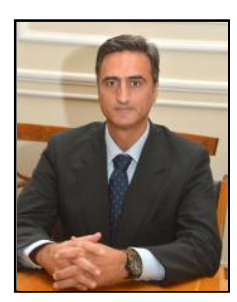

Spyros Spyrou is a professor of finance at the Department of Accounting \& Finance, Athens University of Economics \& Business. Before that he was with the University of Durham (UK), Middlesex University Business School (UK), and Brunel University (UK). He is the director of Postgraduate Studies (Accounting \& Finance) and the director of the Behavioral Finance Lab (BeFin Lab), at Athens University of Economics \& Business. 